\title{
STRESS RESISTANCE OF OWA STICK REINFORCED GRANO- PERIWINKLE CONCRETE SLAB SUBJECTED TO POINT LOAD
}

\author{
Ezeh J.C. ${ }^{1}$, Ibearugbulem O.M. ${ }^{2}$, Inock E.U. ${ }^{3}$, Obiekwe M.O. ${ }^{4}$ \\ ${ }^{I}$ Associate Professor, Civil Engineering, Department, Federal University of Technology Owerri, Imo State, Nigeria \\ ${ }^{2,3,4}$ Civil Engineering Department, Federal University of Technology Owerri, Imo State, Nigeria
}

\begin{abstract}
In the continuous quest for low cost housing delivery in the developing countries, Periwinkle shells have been used in the riverine (Niger-Delta) areas of Nigeria to wholly or partially replace granite in concrete, while Owa stick (Jaundea Pinnata) has been used for decades in reinforcing earthen houses. This paper reports the stress resistance of owa stick reinforced grano-periwinkle concrete slab compared to plain and steel reinforced grano-periwinkle concrete slab. The mix ratio of 1:2:2 was used for the concrete; the ratio of 1:1 was used for granite and periwinkle shells with a water-cement ratio of 0.5. Concrete cubes were casted and used in testing for compressive strength. Slabs of 500x500x100mm were also used to test for the maximum flexural stress under point load. The slabs were simply-supported (ssss) on all the sides. The 28-day compressive strength and density of the concrete was found to be $19.932 \mathrm{~N} / \mathrm{mm} 2$ and $2617.48 \mathrm{~kg} / \mathrm{m} 3$. From this study it can be concluded that owa stick has elastic properties which helps in improving the tensile strength of concrete, though in comparison steel is still preferred, but the stress resistance of owa stick reinforced concrete slab was more than that of plain concrete with the gain in stress of about $4.56 \%$. Also, the brittle failure of concrete was checked due to the elastic property of owa stick.
\end{abstract}

Keywords: Periwinkle, granite, aggregate, concrete, owa stick (Jaundea Pinnata), flexural stress, point load. $* * *$

\section{INTRODUCTION}

In most countries, concrete is widely used for the foundation of most infrastructures. Its large use can be traced to being readily available and its suitable building properties such as the ability to support large compressive loads. However, the use of concrete is limited because of its low tensile strength. For this reason, reinforcement was introduced to take care of the tension that develops in concrete and one of the most popular of reinforcing bars (rebar) is steel. Steel has a relatively high tensile strength as high as $792 \mathrm{~N} / \mathrm{mm}^{2}$, complementing the low tensile strength of concrete. It is available and affordable in most developed countries but unfortunately the reverse is the case in developing and underdeveloped parts of the world like Nigeria. The high cost and low availability of Construction materials has lead researchers to sort for alternative materials for construction in other to provide affordable houses for dwelling. According to Job, Matawal and Achuenu such alternative materials include sawdust, palm-kernel shell, olive seed, and periwinkle shell which can be used to either partially or fully replace aggregate(s) in concrete [1], Oguara [2]; Okpala, [3].

Like most materials, this rock-like solid mass, concrete, has its major strength and weakness in having considerable compressive strength but little or no resistance to tension. The lack of resistance to overcome tensile stress is overcome by providing reinforcement bars e.g steel, in appropriate places (tension Zone). The resulting composite structure is called Reinforced concrete. However, as the demand for concrete structures increases geometrically, there has been a corresponding decrease in the availability of concrete construction materials and a corresponding increase in the cost of the materials.

It is against this background that researches have been carried out to identify other suitable materials, affordable and readily available to either serve as total or partial replacement for steel and coarse aggregate in reinforced concrete works.

In the quest to finding an alternative to steel reinforcement, there have been researches on the use of geogrid by Muda, Sharif, and Hong [4]; the use of bamboo by, Brink and Rush [5], the use of cane by Anioke, Okoro, Maduh, and Madubueze [6] etc as reinforcement materials but the use of other locally available sticks has received little attention. Over the years, "Owa" stick, (Jaundea Pinnata) has been used in the southern part of Nigeria (Akwa Ibom state) in reinforcing mud or earthen houses and it has proven to be a good construction material, hence, the need to study its performance as reinforcement in concrete slab. According to H.M. Burkill, in the book "Useful plants of west tropical Africa (2nd edition), Jaundea Pinnata belongs to the family of Connaracae, a shrub of $6-7 \mathrm{~m}$ tall, or lianascent to the forest canopy. Widely dispersed from Guinea to South Nigeria, and unto Angola, North-East and East Africa

In one of the communities in Akwa Ibom State, it was stated that over the years, owa stick otherwise known as Emong has been used for reinforcing mud or earthen houses because of its 
high durability. They went further to explain its high resitance to insect attacks, low moisture content, stressing that it doesn't absorb moisture once it's dry which gives it an advantage over bamboo. According to Ghavami, bamboo is vulnerable to environmental degradation and attacks by insects and moulds [7]. There is a strong relation between insect attacks and the levels of starch plus humidity content of bamboo cum. In order to reduce the starch content, bamboo receives a variety of treatments including curing on the spot, immersion, heating or smoke. Periwinkles (Nodilittorina radiata) are small greenish blue marine snails with spiral conical shell and round aperture, Adewuyi and Adegoke [8]. The average periwinkle lives three years and grows to a shell height of $20 \mathrm{~mm}$, but the largest recorded periwinkle grew to $52 \mathrm{~mm}$. They are common in the riverine areas and coastal regions of Nigeria where they are used or food. The hard shells, which are regarded as wastes ordinarily posed environmental nuisance in terms of its unpleasant odour and unsightly appearance in open-dump sites located at strategic places, are now being considered as coarse aggregates in full or partial replacement for expensive, unaffordable or unavailable crushed stones or local washed gravels. In Rivers state, Akwa Ibom, and Cross River State, periwinkle shells have been used for many purposes in the past to include construction of houses, soak-away, slabs etc. Since Owa stick and periwinkle shell are naturally occurring materials common to the riverine areas of Nigeria, positive information obtained from this study on the flexural strength of Owa reinforced grano-periwinkle concrete slab will go a long way in minimizing the dependency on steel and granite as reinforcement material and aggregate for concrete slab respectively. Also, it will contribute immensely to housing delivery, especially in the riverine areas of Nigeria where these materials are abundantly available. Besides being readily available, periwinkle shell is considered to be more than 10 times cheaper than granite, and Owa stick can be gotten free or at a negligible price compared to the cost of steel. Hence, if members made from these materials should possess commensurable flexural strength with that of its counterpart, the study can guarantee its use as alternative materials for lightweight concrete constructions especially in areas where the weight of the structure is of great concern.

\section{MATERIALS AND METHODS}

\subsection{Selection of Materials}

The materials used in this research work were cement, water, sharp sand, granite, periwinkle shell, $6 \mathrm{~mm}$ high yield steel, and owa stick. The type of binder or cement used for this research was ordinary Portland cement from Ibeto in conformity with the requirements of BS 12 (1978). For the mixing of the concrete into paste, the water used was borehole water gotten from a tap in Federal Polytechnic, Nekede, Owerri, Imo State. The fine aggregate used in this work was sharp sand gotten from Otamiri River in Nekede, Owerri. The sand was free from deleterious materials.
The coarse aggregate used in this research work included granite. It was a normal weight aggregate gotten from the local market in Owerri, Imo State. It was free from debris. The Periwinkle shells were also used as coarse aggregate in this study. It was gotten from a stock pile in Abak, Akwa Ibom State, where it is wash dried and kept for buyers. It was free from deleterious matters. $6 \mathrm{~mm}$ high yield steel was used as reinforcement for the concrete slabs used as control for the Owa stick reinforced concrete slabs.

It was gotten from the local market in Owerri. Owa stick, Juandea Pinnata, was carefully cut from the bush in Umuchima, Imo State, with a diameter of $8-10 \mathrm{~mm}$ in size. The stick was carefully peeled and dried before cutting them into $450 \mathrm{~mm}$ of length. This was done in other to take care of any decrease in size due to dehydration. The stick was then treated by soaking it in a solution of sodium chloride $(\mathrm{NaCl})$ for 12 hours in order to kill any inherent rodent. It was also steamed for 24 hours to remove the inherent cellulose from the stick. Finally, the stick was sun dried and used for reinforcement of the slab. The reinforcement sticks were arranged with the aid of binding wire and in two sets. The spacing used was same for both the main and distribution reinforcement. The two sets of reinforcements were spaced at $150 \mathrm{~mm}$ and $90 \mathrm{~mm}$ centre to centre.

\subsection{Mix Proportion and Casting of Cubes and Slabs}

A constant mix ratio of 1:2:2 and a water-cement ratio of 0.5 were maintained throughout this work. Batching operation was done by volume because of the nature of periwinkle shells. The fine aggregate used was sharp sand. Cast iron mould of size 150x $150 \times 150 \mathrm{~mm}$ was used in casting concrete cubes while wooden mould of $500 \times 500 \times 100 \mathrm{~mm}$ was used in casting the concrete slabs. Sieve analysis was carried out on sharp sand, periwinkle shells and crushed granite using sieves arranged in decreasing size of opening and shook in order to differentiate samples of the aggregate into fractions. The fraction retained on each sieve size was weighed and recorded. Also the slump test apparatus was cleaned and the wider surface was placed on the steel plate and supported with legs. The apparatus was filled in four layers with concrete; each layer was given 25 blows from a sixteen millimetre tamping rod. The top was smoothened with a trowel. The apparatus was gently and sprightly lifted and placed on the plate near the concrete. The difference in height gave the slump value and was recorded. A representative sample of coarse aggregate (granite and periwinkle shell) drier than the SSD condition was secured. The aggregate was cleaned thoroughly by rolling it in a dry towel and blowing away the dust and fine particles. This help to eliminate the major portion of the very fine material, in which excess of it can introduce considerable error into the test result. The cleaned dry sample was weighed, W1, to nearest gram. It was then placed in a pan and completely covered with water. The sample was kept immersed in water for 24hours. The aggregate was then drained from water and dried to 
saturated surface dry condition (SSD) by airing it. The saturated surface dry condition (SSD) sample was then reweighed, $\mathrm{W}_{2}$. The percentage water absorption was calculated. The cube mould was assembled prior to mixing and properly lubricated for easy removal of hardened concrete cubes. The wooden mould was properly covered with polythene to enhance easy removal and to avoid loss of mixing water to the surrounding. The percentage by volume of crushed granite to periwinkle shells as coarse aggregate was 50:50. The mixing surface was soaked with water two hours prior to concrete mixing to saturate the surface against absorbing mixing water. The mixture was properly turned with shovel until it reached a plastic state which was fed into the moulds. Water curing method was adopted in this project. The specimens were made in accordance with BS 1881. The molded concrete slabs and cubes were kept for 24 hours to set before demoulding. They were then fully immersed into a large curing tank filled with pipe borne water in order to increase the strength of the concrete, promote hydration, eliminate shrinkage and absorb heat of hydration until the age of test. The specimens were cured for 28 days. Prior to testing, the specimens were brought out of the curing tank and air dried for about 2 hours before crushing. The cubes were weighed before testing and the densities of cubes at different time of testing were measured. The compressive strengths of the cubes were tested in accordance to BS 1881 using universal testing machine. The slab was simply supported (SSSS) on all the four sides by steel beams of 50x500mm surface area.

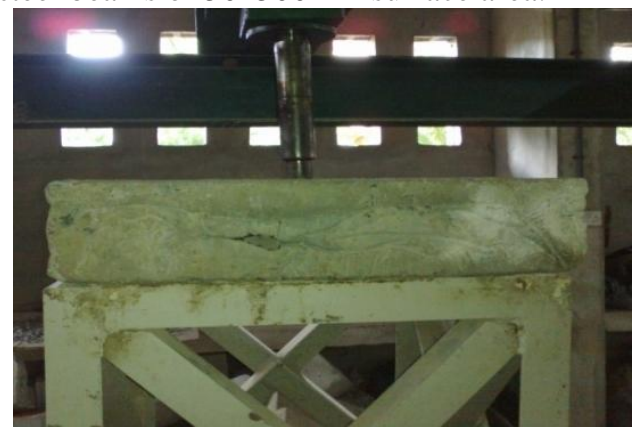

Fig-1: slab subjected to point load

The center of the slab was marked through drawing diagonal lines using a scriber to aid in the application of point load directly to the center. The plunger was $30 \mathrm{~mm}$ diameter. Loading was done gradually at about one minute interval between each thrust; this was to aid in giving time for proper distribution of load in the member. The load was increased until the specimen failed, and the maximum load applied to the specimen during the test was recorded. The slab was considered to have failed once there was a visible crack at the bottom fiber.

\section{RESULTS AND DISSCUSSION}

Chart1, 2, 3 shows the grain size analysis graph for sharp sand, granite and periwinkle shell, indicating well graded samples. At a water-cement ratio of 0.5 , the slump was found to be $18 \mathrm{~mm}$. Table 1 shows the densities of concrete before and after 28days curing. The average density of the concrete resulting from a 1:1 grano-periwinkle aggregate was $2617.48 \mathrm{~kg} / \mathrm{m} 3$. According to BS, normal weight concrete is those with density of 2200 to $2600 \mathrm{~kg} / \mathrm{m} 3$. Therefore, grano-periwinkle concrete at $1: 1$ can be classified as structural normal weight concrete. The 28-day compressive strength tested from the cubes gave strength of $19.52 \mathrm{~N} / \mathrm{mm} 2$, which is close to what was gotten by Osarenmwinda and Awaro in similar mix [9]. According to ACI 213 structural lightweight aggregate concrete is a concrete whose 28-day compressive strength is equal to or greater than $17 \mathrm{~N} / \mathrm{mm} 2$, and also ASTM-77 recommended minimum strength of $17 \mathrm{~N} / \mathrm{mm} 2$ for structural lightweight concrete [10]. Hence, it can be seen that compressive strength is not enough factor to use in classifying concrete, being that its density qualities it for another group.

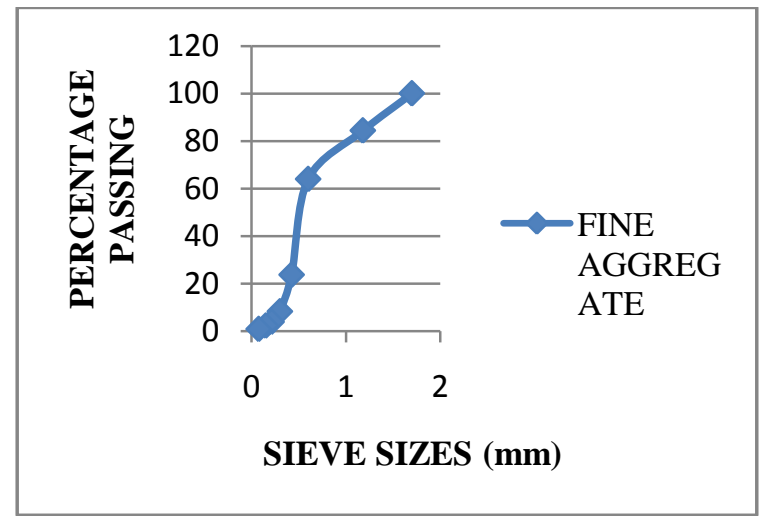

Chart-1 Grain size analysis graph for fine aggregate.

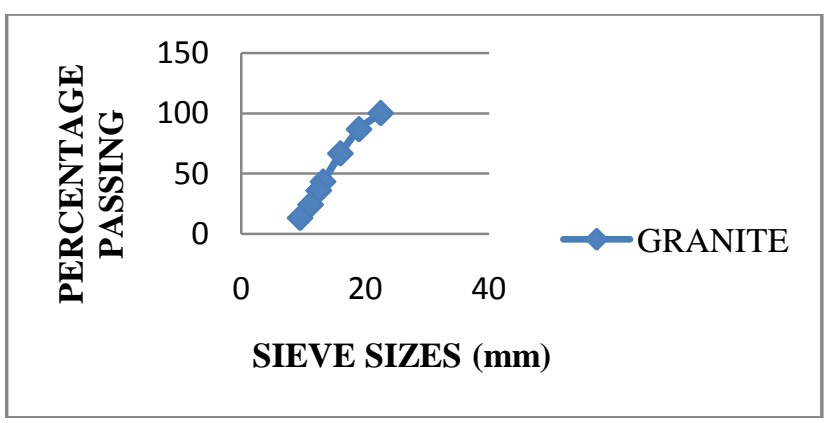

Chart-2 Grain size analysis graph for coarse aggregate (granite).

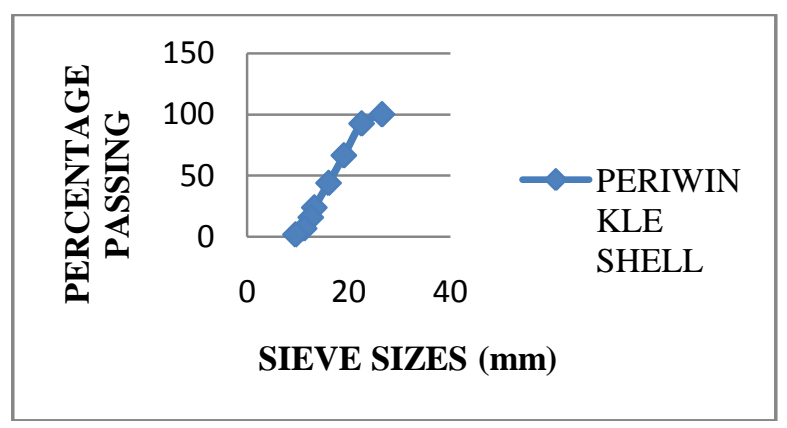

Chart-3 Grain size analysis graph for coarse aggregate (periwinkle). 
Table1. Density Table

\begin{tabular}{|l|l|l|l|}
\hline $\begin{array}{l}\text { SPECIM } \\
\text { EN }\end{array}$ & $\begin{array}{l}\text { SATURA } \\
\text { TED WET } \\
\text { Kg/m }\end{array}$ & $\begin{array}{l}\text { SATURA } \\
\text { TED DRY } \\
\text { Kg/m }\end{array}$ & $\begin{array}{l}\text { SATURATED } \\
\text { SURFACE } \\
\text { DRY Kg/m }\end{array}$ \\
\hline I & 2580.74 & 2571.85 & 2562.96 \\
\hline II & 2554.07 & 2539.26 & 2524.44 \\
\hline III & 2675.56 & 2663.70 & 2651.85 \\
\hline IV & 2500.74 & 2491.85 & 2477.04 \\
\hline V & 2554.07 & 2542.22 & 2524.44 \\
\hline VI & 2841.48 & 2823.70 & 2814.81 \\
\hline VII & 2459.30 & 2441.48 & 2429.63 \\
\hline VIII & 2764.44 & 2752.59 & 2737.78 \\
\hline IX & 2758.52 & 2743.70 & 2728.89 \\
\hline X & 2749.63 & 2731.85 & 2722.96 \\
\hline
\end{tabular}

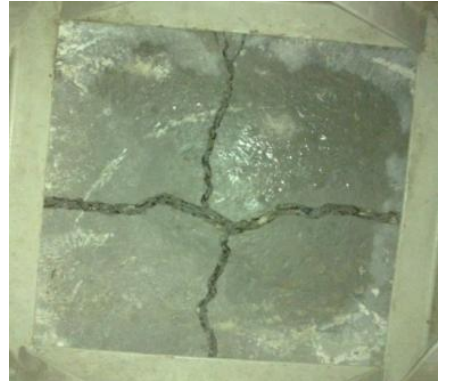

Figure 2 shows the pattern of failure of grano-periwinkle slab when subjected to point load at the centre. The crack in both direction shows that the stress from the load was evenly distributed to all parts of the member. On testing the three different samples with point load, the steel reinforced slab showed high flexural strength and on failure, minimal cracks and crack width were obtained compared to stick reinforced and plain concrete slabs. Similarly, stick reinforced slabs failed with smaller crack width compared to plain concrete. The stick could be classified as ductile material based on its elastic performance in concrete. When loaded to failure point, once the load was removed or reduced, the slab completely recover and returns to its original shape and size; showing the elastic behavior of owa stick as reinforcement. For plain concrete, at the point of failure, the slab fails without any sign showing that is a brittle material with little or no tensile strength. From the results, it was seen that owa stick reinforced concrete was able to carry some amount of tension and did not have brittle failure when compared to plain concrete. From the results, at $90 \mathrm{~mm}$ $\mathrm{c} / \mathrm{c}$ spacing of owa stick reinforcement, the gain in stress of owa stick reinforced slab over plain slab was $4.53 \%$ while at $150 \mathrm{~mm} \mathrm{c} / \mathrm{c}$ spacing, the gain in stress was $1.53 \%$. The reduction can be attributed to the inadequacy of the reinforcement bars.

Fig-2: failed slab subjected to point load

Table2. Failure load of concrete slab reinforced with owa stick, steel, and plain concrete subjected to point load

\begin{tabular}{|l|l|l|l|l|l|}
\hline $\begin{array}{l}\text { SLAB REINFORCEMENT } \\
\text { @ 90mm c/c }\end{array}$ & MARK & $\begin{array}{l}\text { LOAD } \\
(\mathbf{B a r})\end{array}$ & $\begin{array}{l}\text { LOAD } \\
\left(\mathbf{K N} / \mathbf{m}^{2}\right)\end{array}$ & $\begin{array}{l}\text { LOAD } \\
(\mathbf{K N})\end{array}$ & $\begin{array}{l}\text { AVERAGE } \\
\text { LOAD } \\
(\mathbf{K N})\end{array}$ \\
\hline \multirow{3}{*}{ STICK } & A1 & 45 & 4500 & 3.182 & \\
\cline { 2 - 6 } & A1 & 46 & 4600 & 3.252 & 3.276 \\
\cline { 2 - 6 } & A1 & 48 & 4800 & 3.394 & \\
\hline \multirow{3}{*}{ STEEL } & B1 & 78 & 7800 & 5.515 & \\
\cline { 2 - 6 } & B1 & 79 & 7900 & 5.585 & 5.538 \\
\cline { 2 - 6 } & B1 & 78 & 7800 & 5.515 & \\
\hline \multirow{3}{*}{ PLAIN } & $\mathrm{C}$ & 42 & 4200 & 2.969 & \\
\cline { 2 - 6 } & $\mathrm{C}$ & 43 & 4300 & 3.040 & 3.134 \\
\cline { 2 - 6 } & $\mathrm{C}$ & 48 & 4800 & 3.394 & \\
\hline
\end{tabular}

Table 3 Failure load of concrete slab reinforced with owa stick, steel, and plain subjected to point load

\begin{tabular}{|l|l|l|l|l|l|}
\hline $\begin{array}{l}\text { SLAB REINFORCEMENT } \\
\text { @ 150mm c/c }\end{array}$ & MARK & $\begin{array}{l}\text { LOAD } \\
(\mathbf{B a r})\end{array}$ & $\begin{array}{l}\text { LOAD } \\
\left(\mathbf{K N} / \mathbf{m}^{2}\right)\end{array}$ & $\begin{array}{l}\text { LOAD } \\
(\mathbf{K N})\end{array}$ & $\begin{array}{l}\text { AGERAGE } \\
\text { LOAD }\end{array}$ \\
\hline \multirow{3}{*}{ STICK } & A2 & 46 & 4600 & 3.252 & \\
\cline { 2 - 7 } & A2 & 46 & 4600 & 3.252 & 3.181 \\
\cline { 2 - 7 } & A2 & 43 & 4300 & 3.040 & \\
\hline \multirow{3}{*}{ STEEL } & B2 & 57 & 5700 & 4.030 & \\
\cline { 2 - 7 } & B2 & 56 & 5600 & 3.959 & 4.03 \\
\cline { 2 - 7 } & B2 & 58 & 5800 & 4.101 & \\
\hline \multirow{3}{*}{ PLAIN } & $\mathrm{C}$ & 42 & 4200 & 2.696 & 3.134 \\
\cline { 2 - 6 } & $\mathrm{C}$ & 43 & 4300 & 3.040 & \\
\cline { 2 - 6 } & $\mathrm{C}$ & 48 & 4800 & 3.394 & \\
\hline
\end{tabular}


Table4. Maximum flexural strength of slab samples

\begin{tabular}{|c|c|c|c|c|c|c|}
\hline $\begin{array}{l}\text { REINFR. } \\
\text { SPACING } \\
(\mathrm{mm}) \mathrm{c} / \mathrm{c}\end{array}$ & $\begin{array}{l}\text { TYPE OF } \\
\text { RINFR. }\end{array}$ & $\begin{array}{l}\text { FAILURE } \\
\text { LOAD, } \\
\text { KN }\end{array}$ & $\begin{array}{l}\text { MAX. } \\
\text { MOMENT } \\
\text { KNm }\end{array}$ & $\begin{array}{l}\text { MAX. } \\
\text { FLEXURAL } \\
\text { STRESS KN } / \mathrm{m}^{2}\end{array}$ & $\begin{array}{l}\% \text { GAIN IN } \\
\text { STRESS OF OWA } \\
\text { OVER PLAIN } \\
\text { CONCRETE }\end{array}$ & $\begin{array}{l}\% \text { STRESS RESISTANCE } \\
\text { OF OWA R. CONCRETE }\end{array}$ \\
\hline \multirow{3}{*}{90} & STICK & 3.276 & 0.2048 & 245.76 & \multirow{3}{*}{4.56} & \multirow{3}{*}{59.17} \\
\hline & STEEL & 5.538 & 0.3461 & 415.35 & & \\
\hline & PLAIN & 3.134 & 0.1959 & 235.05 & & \\
\hline \multirow{3}{*}{150} & STICK & 3.181 & 0.1988 & 238.58 & \multirow{3}{*}{1.50} & \multirow{3}{*}{78.93} \\
\hline & STEEL & 4.030 & 0.2519 & 302.25 & & \\
\hline & PLAIN & 3.134 & 0.1959 & 235.05 & & \\
\hline
\end{tabular}

The following formulae were used in calculating for various parameters;

The percentage water absorption of periwinkle shells and granite was 4 and 0.4 respectively. This is in-line with Ibearugbulem and it's within the range of values determined for different aggregates of different sizes [11]. However, the water absorption value of periwinkle is different from that reported by Job, Matawal and Achuenu [1], but according to Oguara, the varied absorption values could be due to the varied species available in West Africa [2].

\section{CONCLUSIONS}

From the test carried out on the stress resistance of owa stick reinforced grano-periwinkle concrete slab subjected to point load, the following conclusions can be drawn:

Granite-periwinkle concrete at a ratio of 1:1 in a mix of 1:2:2 can be classified as normal weight concrete because its density is greater than $2000 \mathrm{~kg} / \mathrm{m} 3$.

The flexural strength of owa stick reinforced graniteperiwinkle concrete slab is determined based on the properties of the periwinkle shells; the percentage replacement and the quantity of owa stick reinforcements.

Owa stick has proven to be a good reinforcement material for concrete by providing $4.56 \%$ gain in stress resistance for point load over plain concrete when spaced at $90 \mathrm{~mm} \mathrm{c/c}$, and its elastic nature and durability has helped concrete not to have brittle failure.

Owa stick reinforced granite-periwinkle slab had strength of $59 \%$ when compared to steel reinforced slab at $90 \mathrm{~mm}$ and $78 \%$ at $150 \mathrm{~mm}$ reinforcement spacing except in cases where the slab was under reinforced.

The percentage gain in stress of owa stick reinforced concrete can be enhanced by increasing the quantity of reinforcements.

\section{REFERENCES}

[1]. Job F. O., Matawal, D S. and Achuenu, E. (2009). The characteristics of periwinkle shell as an aggregate in concrete. Nigerian journal of construction technology and management. 10(1\&2); 96-101

[2]. Oguara, T. M. suitability of periwinkle shells as construction aggregates. Paper presented at the conference on Material Testing Control and Research, Portharcourt, Nigeria, 1984.

[3]. Okpala, D. C. (1990). Palm kernel shell as a lightweight aggregate in concrete. Building and environment, 25(4): 29

[4]. Muda, Z. V., Sharif, S. F., and Hong, Y. J. (2012). Flexural behavior of lightweight oil palm shells concrete slab reinforced with Geogrid. International journal of science and engineering research, 3(11). 1- 296.

[5]. Brink, F. E. and Rush, P. J. (1966). Bamboo reinforcement concrete construction. U. S. Naval civil engineering laboratory, Port Hueneme, California.

[6]. Anioke, C.N., Okoro, N.M, Maduh, U.J, and Madubueze, O.C. Effect of cane reinforcement on the modulus of rupture of cane reinforced concrete beam, Federal University of Technology, Owerri, Nigeria, (2007).

[7]. Ghavami, K. (2005). Bamboo as reinforcement in structural concrete elements. Elsevier Ltd, cement and concrete composites 27, 637-649.

[8]. Adewuyi, D.O and Adegoke, T. (2008). Exploration Study of Periwinkle shells as coarse aggregates in concrete work. ARPN, Journal of engineering and applied sciences. Vol. 3(6). [9]. Osarenmwinda, J.O. and Awaro, A. O. (2009). The potential use of periwinkle shell as coarse aggregate for concrete. Journal of advanced materials research. 62-64.

[10]. ACI 213 (1987). Guide for structural lightweight aggregate. ACI committee 213. Pp 38.

[11]. Ibearugbulem, O. M. Mathematical models for optimization of compressive strength of periwinkle shellsgranite concrete. Unpublished master of engineering thesis, federal university of technology, owerri, Nigeria, 2006. 